\title{
DIEGESE EM REPÚBLICA 392d ${ }^{1}$
}

\author{
Jacyntho Lins Brandão ${ }^{2}$ \\ jlinsbrandao@ufmg.br
}

RESUMO Este artigo enfoca o uso do termo diégesis em República 392d, concluindo que não deve ser entendido simplesmente como "narrativa", mas abrange outras formas de exposição conduzidas por um diegetés. Ressalta ainda que a diégesis, a que se reduz tudo quanto dizem mitólogos e poetas, é um gênero de discurso relevante também para a transmissão dos lógoi socráticos, o que poderia explicar a necessidade de reflexão, por parte de Platão, sobre o lógos dos poetas.

Palavras-chave Platão; Narrativa; Mimese; Poesia; Diálogo Socrático; Gêneros de Discurso.

ABSTRACT The article focuses on the use of the term diegesis in Republic 392d and concludes that it should not be understood simply as "narrative", since it covers other kinds of accounts carried out by a diegetes. It brings out the fact that diegesis, to which everything that is said by mythologists and poets is reduced, is also a discourse genre relevant to the transmission of Socratic logoi, and that could explain why Plato has to reflect upon the poets'logos.

Keywords Plato; Narrative; Mimesis; Poetry; Socratic Dialogue; Discourse Genres.

1 Este artigo é parte de um estudo mais amplo, relativo às teorizações sobre a literatura na Grécia antiga (as quais têm início justamente com a reflexão platônica, na República), levado a cabo com o apoio do Conselho Nacional de Desenvolvimento Científico e Tecnológico - CNPq. Agradeço, em especial, a Maria das Graças de Moraes Augusto, da Universidade Federal do Rio de J aneiro, pelas discussões que me permitiram refinar minha compreensão sobre Platão.

2 Faculdade de Letras, UFMG, Belo Horizonte, Brasil. Artigo recebido entre 01 e 30 de setembro e aprovado entre 01 e 31 de outubro de 2007.

KRITERION, Belo Horizonte, no 116, Dez/2007, p. 351-366. 
A discussão sobre a léxis própria dos poetas é introduzida, na República, pela seguinte declaração de Sócrates: "porventura tudo quanto é dito por mitólogos ou poetas não é diégesis sobre coisas que foram, são ou serão?"3 Essa definição busca dar conta do não entendimento de Adimanto sobre o que seria a léxis, uma vez que Sócrates acabara de afirmar: "Isso então, o relativo ao lógos, tenha fim; o que respeita à léxis, como creio, depois disso é preciso examinar - e tanto o que se deve dizer (há lektéon), quanto como se deve dizer (hos lektéon) estará completamente examinado por nós." ${ }^{4}$ Ora, "o que se deve dizer" referindo-se ao que acabara de ser investigado, o lógos, é ao "como se deve dizer" ou à léxis que se aplica agora a definição de que, em se tratando de mitólogos e poetas, ela se configura como "diegese". 5

Trata-se aparentemente de um detalhe, porém relevante, por diversas razões. A primeira, mais imediata, por ser sobre essa base (o lógos diegético) que Platão procederá à distinção dos três tipos de léxis, a saber, nos próprios termos socráticos: "porventura, então, não é com simples diegese (haplêi diégesei), ou com a [diegese] que vem a ser através de mimese (dià miméseos gignoménei) ou através de ambas (di' amphotéron) que eles [mitólogos e poetas] levam a

3 Ar oujpanta o\$a upovmugologwn h]pointwa legetai dihghsił ousa tugcanei h]gegonontwn h]ohtwn h] mel I ontwn; República 392d. Por comodidade e para evitar a interferência de sentidos alheios, opto, na exposição, por termos os mais transparentes possível (como "mitólogo", "diegese" etc.). A lógos (discurso) e léxis (elocução ou estilo) me referirei sempre sem traduzir as palavras gregas, fazendo apenas uma observação: se I egein corresponde a "dizer", então I exi ৎ equivale a "dicção", no sentido do modo como se diz algo. Tratei dessa questão, de modo geral, em BRANDÃO, J. L. Arqueologia da léxis. In: PERES, Ana Maria Clark; PEIXOTO, Sérgio Alves; OLIVEIRA, Silvana Maria Pessôa de. 0 estilo na contemporaneidade. Belo Horizonte: Faculdade de Letras da UFMG, 2005. p. 29-39 (embora neste trabalho ainda mantenha o entendimento de dihghsis simplesmente como "narrativa", o que prejudica algumas de minhas conclusões).

4 TaVmeb dhVlogwn pevi ejetw tevoj: toVdeVIerews, wh egwVoimai, metaVtouto skepteon, kaiVhmin a \{te lekteon kaiVws l ekteon pantel we éskey et ai. República 392c.

5 Em 392b, como sorte de conclusão do percurso relativo ao lógos, Sócrates declara: ka i Vt a Vmebl t o i a uka apereia legein, taVd' ejantia toutwn prostaxein abein te kaiVmuqologei ("e coisas desse tipo proibiremos que digam, mas o contrário disso determinaremos que tanto cantem, quanto contem"). Observe-se que o mythologeîn está sempre em causa, neste caso em complementaridade com "cantar". Não tratarei aqui do problema que levanta o uso de mythológos em 392d, restringindo-me a dar apenas duas indicações esclarecedoras: a) em República 380c, na conclusão do exame que conduzirá à primeira lei relativa a como se devem representar os deuses ("deus não é causa de tudo, mas só dos bens"), Sócrates declara que, do modo como o fazem geralmente os poetas, não se permitirá que, dentre outras coisas, qualquer pessoa, "nem com metros, nem sem metros, conte mitos" (mh $v$ ' ej metr w/mhte aheu metr o u mu qo l o gount a ); b) em Fédon 61b, Sócrates, instado pelo sonho a dedicar-se à música, afirma que, "considerando que o poeta deve, se quer ser poeta, criar (ou versificar) mitos (p o i ei a mu qou c) e não lógoi, e não sendo eu próprio mitólogo (mu qologikołs), por isso então os mitos que tinha à mão e conhecia, os de Esopo, desses pus em versos (epoibsa) os primeiros que me ocorreram". Assim, a mythología ou o mythologeîn pode ser tanto em verso quanto em prosa - embora o exemplo de mythológos, por excelência, seja Esopo, que compôs mythoi em prosa. Dizendo de outro modo: como a mimese à diegese, o verso é um traço que se pode acrescentar ao mythos, sendo, portanto, o poeta um tipo específico do mythológos. Conclusão: todo poeta é mitólogo, mas nem todo mitólogo é poeta. 
cabo [tudo quanto dizem]?" A segunda razão está em que se trata do gesto inaugural da (nossa) teoria literária que, retomada por Aristóteles, se revelou capaz de fornecer as balizas para a distinção dos gêneros numa longuíssima duração. ${ }^{7} \mathrm{Na}$ esteira dessa importância inaugural, é a partir do entendimento de diégesis como "narrativa" e de mímesis como "representação" que a crítica passou a postular que "o que chamamos de poesia lírica" e outras formas de literatura ficaram fora do interesse de Platão - e, já que o modelo que ele inaugura conhecerá grande sucesso, a lírica teria permanecido, durante toda a Antigüidade, um gênero sem teorização. ${ }^{8}$ Finalmente - este é o ponto que aqui interessa -, a própria palavra diégesis não se registra antes de Platão, o que poderia sugerir que este a tivesse criado ou, pelo menos, que podia transportála para o núcleo de sua teoria poética como um termo não excessivamente marcado. ${ }^{9}$

Digno de nota é ainda o fato de que o verbo diegeîsthai - donde derivam diégesis, diégema e diegetés - não seja atestado antes do século V a.C. Nessa época, ele entra efetivamente em cena, passando a concorrer com outras palavras que cobriam a mesma esfera semântica (a mais antiga das quais parece ser mythéesthai - mas não menos importante sendo também légein, largamente utilizada por Heródoto). O quadro a seguir apresenta a distribuição das

6 Ar' ouh oufivhfoi aplhtdihghsei h]diaVmimhsews gignomenh/hldi' a mfoterwn perainousin; República 392d.

7 A retomada por Aristóteles procede a uma mudança no modelo platônico de grandes conseqüências, ao deslocar seu ponto de referência: não mais a diegese, mas a mimese. Isso embora o resultado para a classificação dos gêneros não deixe de permanecer o mesmo: a) uma apangelía (narração) que se pode fazer "como si mesmo e não mudando" (a "diegese simples" de Platão); b) a que se faz "tornando-se em algo outro", como Homero (a diegese que, em Platão, usa tanto de "diegese simples" quanto de mimese); c) finalmente, com todos "os mimetizados agindo e atuando", ou seja, o drama (a diegese que vem a ser através de mimese).

8 Cf. GENETTE, G. Géneros, "tipos", modos. In: GARRIDO GALLARDO, M. A. Teoría de los géneros literarios. Madrid: Arco, 1988. p. 188-189: “Platão só considera aqui as formas de poesia 'narrativa', no mais amplo sentido da palavra. A tradição posterior, depois de Aristóteles, ao inverter os termos, preferirá dizer 'mimética' ou representativa: aquela que 'conta' sucessos, reais ou fictícios. Platão exclui deliberadamente toda poesia não representativa, sobretudo o que chamamos de poesia lírica, e, com maior razão, qualquer outra forma de literatura (incluída ainda toda possível 'representação' em prosa, como nosso romance ou nosso teatro moderno)."

9 Além de no corpus platonicum, o único outro registro de diégesis encontra-se no corpus hippocraticum (Da dieta na enfermidade aguda 14). O caráter aberto de diégesis na República impõe, aos tradutores, uma tarefa difícil: Émile Chambry verte o termo como "récit" (PLATON. La République. Paris: Les Belles Lettres, 1932); Maria Helena da Rocha Pereira adota, em português, "narrativa" (PLATÃO. A República. Lisboa: Calouste Gulbenkian, 1980), o que é também a opção de Anna Lia Amaral de Almeida Prado (PLATÃO. A República. São Paulo: Martins Fontes, 2006), bem como (em espanhol, "narración") de Antonio Camarero (PLATÓN. República. Buenos Aires: Editorial Universitaria, 1998). Carlos Alberto Nunes opta por mais de um correspondente em português: "relato", "exposição", "narrativa", "narração" - destaca-se, especialmente, o uso de "simples exposição" e "exposição simples" para haplè diégesis, em 392d e 393d, respectivamente (PLATÃO. A República. Belém: EDUFPA, 2000). 
primeiras ocorrências de diegeîsthai e seus derivados nos autores que utilizam esses termos até a época de Platão (cf. o Thesaurus Linguae Graecae):

TABELA 1

Ocorrências de diegéomai e seus derivados até a época de Platão

\begin{tabular}{|c|c|c|c|c|c|c|c|}
\hline & $\begin{array}{l}\overline{0} \\
\overline{8} \\
\delta \\
\delta \\
\bar{y} \\
\overline{0}\end{array}$ & 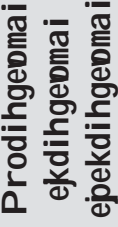 & $\begin{array}{l}5 \\
0 \\
\stackrel{5}{5} \\
\frac{5}{9} \\
5 \\
\overline{0} \\
0\end{array}$ & $\begin{array}{l}\frac{1}{1} \\
\frac{1}{9} \\
\frac{1}{7} \\
\overline{7} \\
\overline{7}\end{array}$ & $\begin{array}{l}n \\
\bar{n} \\
\frac{1}{n} \\
\frac{1}{\sigma} \\
\bar{j}\end{array}$ & $\begin{array}{l}\frac{6}{0} \\
\frac{5}{2} \\
\frac{1}{\overline{0}}\end{array}$ & 胥 \\
\hline Platão & 47 & 3 & 0 & 0 & 21 & 0 & 71 \\
\hline Xenofonte & 56 & 0 & 2 & 0 & 0 & 0 & 58 \\
\hline Isócrates & 11 & 0 & 0 & 1 & 0 & 0 & 12 \\
\hline Lísias & 11 & 0 & 0 & 0 & 0 & 0 & 11 \\
\hline C. hipocrático & 6 & 2 & 0 & 0 & 1 & 1 & 10 \\
\hline Esopo & 7 & 0 & 0 & 0 & 0 & 0 & 7 \\
\hline Andócides & 4 & 0 & 0 & 0 & 0 & 0 & 4 \\
\hline Antifonte & 4 & 0 & 0 & 0 & 0 & 0 & 4 \\
\hline Aristófanes & 2 & 0 & 0 & 0 & 0 & 0 & 2 \\
\hline Pródico & 2 & 0 & 0 & 0 & 0 & 0 & 2 \\
\hline Epimênides & 1 & 0 & 0 & 0 & 0 & 0 & 1 \\
\hline Heráclito & 1 & 0 & 0 & 0 & 0 & 0 & 1 \\
\hline Heródoto & 0 & 1 & 0 & 0 & 0 & 0 & 1 \\
\hline Tucídides & 1 & 0 & 0 & 0 & 0 & 0 & 1 \\
\hline Iseu & 1 & 0 & 0 & 0 & 0 & 0 & 1 \\
\hline Total & 154 & 6 & 2 & 1 & 22 & 1 & 186 \\
\hline
\end{tabular}

Não pretendo atribuir à estatística mais do que lhe compete: como Apolo em Delfos, ela nem afirma nem nega, mas dá sinais. Todavia, alguns dados são significativos: a) a concentração de usos pelos dois principais transmissores da memória de Sócrates, a saber, Platão e Xenofonte; b) a relativa alta incidência em 
oradores (Isócrates, Lísias, Andócides, Antifonte); c) a baixíssima ocorrência nos narradores por excelência (Heródoto e Tucídides); d) finalmente, o significativo uso dos termos em pauta no corpus hippocraticum. Não disporei de espaço para analisar cada um desses registros, motivo por que me restrinjo a salientar apenas os que me parecem mais significativos para compreender o uso platônico.

Antes de todos, o que parece mais antigo (do verbo diegeûmai), no fragmento DK 22 B 1 de Heráclito, que cito na tradução de Schüler:

Embora seja este o discurso (lógos), sempre, os homens tardam, não só antes de ouvi-lo, como logo que o ouviram; pois, mesmo que todas as coisas aconteçam de acordo com este discurso (lógos), mostram-se semelhantes a inexperientes ao experimentarem tais palavras e atos que eu persigo (diegeûmai) segundo a natureza distinguindo cada coisa e mostrando como ela é. ${ }^{10}$

Em que pese a proverbial obscuridade de Heráclito e as dificuldades que os fragmentos levantam em termos de interpretação (e conseqüente tradução para nossas línguas e hábitos mentais), o que interessa é que a diegeûmai se apliquem "tanto palavras quanto obras" (kaì epéon kaì érgon) e que o mesmo verbo implique, pelo menos da forma como leio o texto, uma associação com o distinguir (diairéon) e com o dizer (phrázon): "eles assemelham-se a inexperientes, experimentando tanto palavras quanto obras tais quais eu próprio refiro, segundo a natureza, distinguindo cada uma e dizendo como é". Assim, parece que diegeûmai supõe que se separe coisa de coisa e que, a partir disso, se possa detalhar o que é cada qual. Nesse contexto, a relação que a etimologia sugere interessa, já que hegéomai significa "conduzir", "seguir na frente", "guiar", "capitanear" e "governar". Quem diegeîtai de fato conduz o discurso, o que suporia a separação das palavras e obras às quais ele se refere, a imposição de uma distinção que torna possível delas falar - ao contrário do que ocorre com os outros homens, aos quais escapa quanto fazem estando acordados, do mesmo modo que se esquecem do que fazem enquanto dormem (fr. DK 22 B 1). Ora, sem a ação de diegeîsthai, o experimentar

10 SCHÜLER, Donaldo. Heráclito e seu (dis)curso. Porto Alegre: L\&PM, 2000. p. 14-15. 0 tradutor explica assim sua opção ao verter diegeûmai: “A forma verbal diegeûmai ou diegéomai (persigo), derivada de hegémon, chefe de tropas, tem ressonância militar. Isso não surpreende num autor para quem o conflito é o pai de todas as coisas. Adversário de Homero, Heráclito apresenta-se como diegeta, narrador épico de uma campanha de que ele próprio é protagonista." Por seu lado, Souza prefere o verbo "discorrer", escrevendo: "pois tornando-se todas (as coisas) segundo esse logos, a inexperientes se assemelham embora experimentando-se em palavras e ações tais quais eu discorro segundo (a) natureza distinguindo cada (coisa) e explicando como se comporta" (SOUZA, J osé Cavalcante. Os pré-socráticos: fragmentos, doxografia, comentários. São Paulo: Abril Cultural, 1978. p. 79). 
(palavras e obras) assemelha-se, portanto, ao não experimentar, os contrários se confundem e, em palavras e obras, parece faltar justamente a condução de quem capitaneia e governa. Ao "tudo vem a ser conforme o lógos" parece corresponder o "diegeûmai conforme a natureza" - ou, numa outra leitura possível, o diegeûmai sobre palavras e obras que eu distingo conforme a natureza e declaro como cada uma é. Em qualquer das hipóteses permanece a idéia de que diegeîsthai supõe essa distinção e declaração.

Com efeito, nos textos indicados na Tabela 1, diegeîsthai pode apresentar as seguintes acepções: a) diegeîsthai um sonho (contar um sonho) ${ }^{11}$ b) diegeîsthai o que se viu (contar o que se viu) ${ }^{12}$ c) diegeîsthai acontecimentos, ${ }^{13} \mathrm{com}$ destaque para fazê-lo na Assembléia ${ }^{14}$ ou no tribunal (narrar ou descrever) ${ }^{15}$ d) diegeîsthai uma situação (descrever) ${ }^{16}$ e) diegeîsthai o modo de ser de alguém (descrever) ${ }^{17} \mathrm{f}$ ) diegeîsthai a beleza de alguém (descrever) ${ }^{18} \mathrm{~g}$ ) diegeîsthai um caráter, neste caso, o de Sócrates (descrever); ${ }^{19} \mathrm{~h}$ ) diegeîsthai performances, neste caso, as de Sócrates (descrever) $;{ }^{20}$ i) diegeîsthai uma vida (narrar e descrever); ${ }^{21} \mathrm{j}$ ) diegeîsthai a natureza, o corpo, a saúde e a doença (expor);22 1) diegeîsthai as motivações de alguém num tribunal (expor); ${ }^{23} \mathrm{~m}$ ) diegeîsthai um plano (expor), ${ }^{24} \mathrm{n}$ ) diegeîsthai um argumento (expor) ${ }^{25} \mathrm{o}$ ) diegeîsthai com alguém, em uso intransitivo (conversar). ${ }^{26}$ Desses usos, valerá a pena destacar três.

11 EPIMÊNIDES 1, 18; XENOFONTE. Anábase IV, 3, 8. Recorde-se que este uso está em relação com o seguinte, pois o sonho se encontra na esfera das coisas vistas: literalmente, diz-se, em grego, que "Xenofonte viu um sonho" (ónar eîden) e depois o contou.

12 XENOFONTE. Anábase IV, 3, 11-13.

13 ARISTÓFANES. Vespas 1996; ESOPO 183, 1-3, 254; HERÓDOTO IV, 145; TUCÍDIDES VI, 54; XENOFONTE. Helênicas IV, 8, 1.

14 XENOFONTE. Helênicas I, 7, 3-5.

15 ANDÓCIDES. Sobre seu retorno 14; Contra Alcibíades 25; ANTIFONTE. Contra a madrasta 13, 8; Do dançarino 8, 2; LíSIAS I, 9, 2; I, 22, 3; III, 3, 6; XIII, 4, 7; ISÓCRATES. Egineta IV, 10; Eutino II, 2. Um torneio comum, que poderia ser classificado no âmbito dos recursos retóricos, é afirmar que seria longo diegeîsthai algo (cf. LíSIAS 23, 11; ANDÓCIDES. Sobre a paz 9).

16 XENOFONTE. Helênicas IV, $2,2$.

17 XENOFONTE. Anábase VII, 4, 7-8.

18 XENOFONTE. Memoráveis III, 11, 1-2.

19 XENOFONTE. Memoráveis IV, 8, 11.

20 XENOFONTE. Memoráveis IV, 3, 2-3.

21 XENOFONTE. Ciropedia I, 1.

22 HIPÓCRATES. Sobre os ares, as águas e os lugares 7, 1; Da dieta I-IV, 61, 1; Da inseminação, da natureza das crianças e das doenças IV, 13, 4; Das articulações 33, 7; Das doenças do povo 6, 2, 24, 2.

23 ANDÓCIDES. Sobre os mistérios 117.

24 ARISTÓFANES. Aves 198.

25 XENOFONTE. Memoráveis III, $1,1$.

26 ESOPO 301. Trata-se de ocorrência excepcional, a que se acresce a dificuldade de datar com precisão 0 texto que recebemos das fábulas. 
Primeiramente, os que se registram no corpus hippocraticum. Em Sobre os ares, as águas e os lugares, afirma o autor que "desejo discorrer sobre o restante das águas" (perì dè tôn loipôn hydáton boúlomai diegésasthai), esclarecendo que tratará "tanto das que são doentias, quanto das saudáveis, de quais águas vêm a ser naturalmente más e de quantas são boas" $(7,1)$. Como se vê, está em jogo o separar e distinguir como base para o diegeîsthai, o que se repete em Da dieta, quando se afirma que "a respeito dos sofrimentos, que tipo de poder (dýnamin) eles têm, exporei (diegésomai)", passando-se imediatamente à exposição: "pois se há os que são naturais, há também os que se devem à violência" (I-IV, 61, 1). Em Da inseminação, da natureza das crianças e das doenças, afirma-se: "como vejo que é a fecundação no sexto dia, exporei (diegésomai)", dando-se início a uma detalhada descrição (IV, 13, 4). No livro Das articulações procede-se a um comentário de ordem metatextual bastante importante, quando se declara que "ainda que não seja fácil relatar com precisão (atrekéos diegéesthai), por escrito, toda a cirurgia, deve ele [o leitor] fazer dela uma idéia (hypotopéesthai), a partir do que foi escrito" (33, 7). Assim, opõe-se, de um lado, o que se diria de um modo preciso, através do relato, ao que não se faz dessa forma, sendo necessário, por isso, contar com a suposição de quem lê. Encontramo-nos, com efeito, numa esfera em que a exatidão com que se relata e se entende é absolutamente relevante, pois o médico deve basear-se não só no que se encontra exposto nos livros, mas, igualmente, enquanto praticante de uma tékhne, no que lhe expõe o doente que tem diante de si. Em Das doenças do povo, a propósito da orientação do enfermo (he perì tòn nosoûnta oikonomíe) e do que lhe perguntar sobre a doença (es tèn noûson erótesis), arrolam-se, como instrumentos, "as coisas que ele relata, quais são, como se deve compreendê-las, e os discursos" (hà diegeîtai, hoîa, hos apodektéon, hoi lógoi, 6, 2, 24, 2).

É provável que a especialização de diegeîsthai como fazer uma narrativa de fatos tenha se dado em uma outra esfera igualmente sensível para a exatidão das palavras: a dos tribunais. Os exemplos são inúmeros e acabam por configurar lugares-comuns, como em Antifonte: "a respeito dos acontecimentos tentarei relatar-lhes a verdade" (diegésasthai tèn alétheian). Em todos os casos, diegeîsthai supõe um relato ordenado, no sentido da norma que Hermógenes atribui a Isócrates: "pois também Isócrates, em sua arte retórica, diz que, na exposição (diegései), deve ser dito o fato (prâgma), os antecedentes (tà prò toû prágmatos), as conseqüências (tà metà tò prâgma) e os desígnios (tàs dianoías)" (fr. 6.1, Walz) - e, ainda, que "se deve expor o que aconteceu em primeiro lugar, em segundo lugar e o restante seqüencialmente" (diegetéon dè tò prôton kaì tò deúteron kaì tà loipà hepoménos, fr. 10, 12). 
Ora, essa norma poderia aplicar-se às demais formas de diégesis, mesmo as que não se aplicam à narração de acontecimentos, como no seguinte exemplo das Memoráveis de Xenofonte, quando é o próprio Sócrates quem relata a Aristipo o episódio da escolha de Héracles entre dois caminhos: o da virtude ou o do vício. Após o Vício tentar convencê-lo a escolher sua via, a Virtude retruca:

Não enganarei a você com proêmios lisonjeiros, mas, como os deuses estabeleceramnas, exporei as coisas com verdade (tà ónta diegésomai met'aletheías), pois do que é bom e belo nada os deuses dão aos homens sem fadiga e preocupação: se você quer que os deuses lhe sejam propícios, é preciso servir os deuses; se você quer ser amado pelos amigos, é preciso beneficiar os amigos; se você deseja ser honrado por alguma cidade, é preciso ser útil à cidade; se você deseja ser admirado por toda a Grécia em vista de sua virtude, é preciso tentar fazer bem à Grécia; se você quer que a terra lhe traga frutos irrepreensíveis, é preciso cuidar da terra; se você julga dever enriquecer com os rebanhos, é preciso preocupar-se com os rebanhos; se você quer também pelo desejo da guerra crescer, para poder libertar os amigos e prejudicar os inimigos, é preciso aprender a arte da guerra com os entendidos e exercitar como deve ser utilizada; e se você quer também ter um corpo vigoroso, para que sirva à mente, é preciso habituar o corpo a isso e exercitá-lo com fadiga e suor. (II, 1, 27-28)

Citei a íntegra do que a Virtude anunciou que exporia, para que se perceba como o conteúdo, neste caso, se realiza como uma série de conselhos, articulados em forma de hipóteses sobre desejos e os requisitos para sua realização (se você quer..., então é preciso...), ou seja, trata-se de um discurso que, sendo parenético, se volta para o futuro (e recorde-se como Platão admite que a diegese de mitólogos e poetas possa ser também sobre o futuro). Que se trata de diégesis não parece haver dúvidas, pois, tão logo a Virtude fecha sua exposição, “o Vício, retrucando, fala (como diz Pródico): Medite, ó Héracles, como esta mulher expõe (diegeîtai) para você um caminho difícil e longo para a alegria; eu, de minha parte, por um caminho fácil e rápido o conduzirei à felicidade" (II, 1, 29).

Esses exemplos, não sendo exaustivos, são todavia suficientes para permitir-nos ampliar a concepção do que seja diegeîsthai, termo que cobre a esfera de relatar, contar, expor - em suma, discorrer, que talvez fosse a escolha mais adequada, já que o termo guarda a idéia de que se procede a um percurso (conforme o correspondente latino discurrere). Uma vantagem de adotarmos essa acepção geral está em que o verbo discursare, ainda em latim, significa "ir e vir", "andar a correr por diversas partes", bem como discursus tem o significado de "o correr ou discorrer para diversas partes", donde "discurso", "dissertação", "conversa". Ora, hegeîsthai, de que deriva diegeîsthai, encontra-se também no campo semântico dos deslocamentos, 
significando "ir à frente", "conduzir" - o que tem como conseqüência ressaltar que, enquanto diegético, o discurso é um percurso, sendo o elemento mais importante de sua constituição aquele que o conduz de modo hegemônico: o diegeta. ${ }^{27}$

Tanto em Platão como em Xenofonte pode-se constatar que o diegeîsthai tem uma função destacada na conservação dos ensinamentos de Sócrates. Assim, por exemplo, o Econômico constrói-se como uma série de relatos distribuídos em vários níveis: a) o do narrador (voz autoral); b) o dos que dialogam (Sócrates e Critobulo); c) o dos que dialogam em segundo nível, no diálogo narrado por Sócrates a Critobulo (Sócrates e Iscômaco). O narrador de primeiro nível, que, em princípio, se identifica como o próprio Xenofonte, manifesta-se diretamente no breve prólogo ("eu o ouvi, um dia, conversando - dialegoménou - sobre economia, nestes termos"), mantendo sua presença através dos verbos dicendi (ele disse, disse Sócrates, disse Critobulo) até aproximadamente o primeiro terço da obra - quando então passa a dividir a função diegética com Sócrates, que se manifesta entremeando às suas falas e às do interlocutor, além de pequenos trechos descritivos, também verbos dicendi (eu disse, ele/Iscômaco disse). ${ }^{28}$

Adiantei em outro trabalho a hipótese de que, do ponto de vista narratológico, um dos papéis de Sócrates nos diálogos platônicos é o de representar as funções do narrador, ${ }^{29}$ o que agora quero retomar com um pouco mais de precisão, dizendo que, se cabe a Platão, enquanto autor, o papel hegemônico de diegeta (mesmo naqueles diálogos que apresentam a forma da diegese mimética), o que ele deseja transmitir a seu leitor é que a Sócrates incumbe, de fato, a condução - e não só da discussão representada, como também da diegese da mesma. Parece que isso vem a ser um elemento importante (tratando-se de alguém que não deixou obra escrita) por duas razões: a primeira, porque, pelo que se supõe a partir de Eutidemo, Teeteto, Cármides, Lísis, República e Teeteto, Sócrates, além de conduzir diálogos, parece ter sido também um exímio diegeta de diálogos acontecidos e protagonizados por ele mesmo (o que a exposição de seu diálogo com Iscômaco, no Econômico,

27 Esses sentidos estão presentes também em outras palavras que compartilham o mesmo espaço semântico de diegéomai, como diérkhomai, diexérkhomai, díeimi, "percorrer", "percorrer com a palavra", "expor", "explicar", e diéxodos, "trajeto", "exposição", "descrição" (cf. FOURNIER, H. Les verbes de "dire" en Grec ancien (exemple de conjugaison supplétive). Paris: Librairie C. Klincksieck, 1946. p. 51, 59).

28 No interior do diálogo, as ocorrências de diegeîsthai podem ser esclarecedoras: em IV, 20, o que Lisandro contou sobre Ciro a um hóspede; em V, 1, com referência ao episódio anterior, afirma Sócrates: "esses fatos, Critobulo, eu conto porque..."; em VI, 12, Sócrates pergunta a Critobulo se quer que ele Ihe conte seu encontro com Iscômaco; em VII, 9, Sócrates pede a Iscômaco que lhe conte o que ensinara a sua mulher.

29 BRANDÃO, J. L. A invenção do romance. Brasília: Ed. UnB, 2005. p. 106-110. 
confirma por meio de um testemunho não-platônico); a segunda, porque, num ambiente em que vários autores transmitem, oralmente ou por escrito, relatos dos diálogos socráticos, convém a Platão, que cuida de registrar não ter presenciado pessoalmente nenhum deles, dar a entender que se baseia não só na versão de pessoas bastante próximas do filósofo e fidedignas (como Fédon, Céfalo e Euclides), como também na versão mais legítima dentre todas, ou seja, a do próprio Sócrates. ${ }^{30}$ Essas são razões suficientes, acredito, para justificar a tematização da própria diégesis não apenas como parte de um universo paralelo (o dos poetas), mas como assunto de interesse e conseqüências filosóficas. ${ }^{31}$ Com efeito, no diálogo platônico, o que se narra ou expõe faz parte efetiva da argumentação. É nesse sentido que, na República, impõe-se considerar a diegese de mitólogos e poetas não como uma teorização sobre a literatura em si e por si, mas porque integra uma etapa indispensável e necessária para o exame e a compreensão do lógos. ${ }^{32}$

Consideremos os usos platônicos do verbo e do substantivo, a partir do número de ocorrências nos diálogos:

30 Não se trata aqui de considerar a existência ou não de diegese nos diálogos, já que a maior parte deles comporta esse recurso, mas de ter em vista apenas os diálogos narrados, que se distribuem por dois grupos: a) aqueles em que, após um prólogo dialógico destinado a apresentar o narrador e o narratário (ou narratários), passa-se ao relato de um diálogo socrático acontecido no passado, categoria em que se incluem, com características próprias, Protágoras, Eutidemo, Banquete, Fédon e Teeteto; b) e um segundo grupo, integrado pelo Parmênides (narrativa de Céfalo), bem como por Cármides, Lísis e República (narrativas de Sócrates), em que se dispensa qualquer prólogo dialógico, a narrativa oferecendo-se sem outros enquadramentos, embora, no seu curso, se conheçam quem são os narradores, o narratário permanecendo não identificado (e, por isso, podendo identificar-se com o leitor).

31 Nesse sentido, tendo em vista as passagens diegéticas presentes nos prólogos dos diálogos, Desclos afirma que sua função é "contribuir para a elaboração de uma ficção, a de uma biografia histórica de Sócrates, ou seja, a primeira história filosófica da filosofia" (DESCLOS, Marie-Laurence. La fonction des prologues dans les dialogues de Platon. Recherches sur la philosophie et le langage, n. 14, p. 15-29).

32 Essa necessidade parece especialmente relevante para o estabelecimento do tipo de lógos a ser admitido na cidade, quando se tratar de falar não mais sobre deuses e heróis, mas sobre os homens, o que exige que se perfaça o percurso completo para saber-se o que é a justiça, a saber: a) resta tratar apenas de mais uma lei, a que diz respeito a como deve ser o lógos sobre os homens (392a); b) no momento, contudo, é impossível dizer quais serão as normas relativas a isso, porque os poetas e prosadores (logopoioí) cometem os maiores erros (kakôs légousin) exatamente nessa esfera, dizendo que "há muitos felizes que são injustos e infelizes que são justos", o que Ihes será proibido afirmar (392a-b); c) assim, sobre os homens, já que se deve falar deles como se deve, será preciso esperar, antes de expressar as regras, até "quando descubramos o que é a justiça e como ela é, por natureza, vantajosa para o que a tem, parecendo ou não parecendo ele ser justo" (392c). É exatamente neste momento que Sócrates interrompe a discussão sobre o lógos, passando a tratar da léxis. Não será necessário ressaltar que o problema que fica em suspenso é o tema de toda a República, a cuja conclusão só se chegará ao fim do diálogo. (Agradeço a Maria das Graças de Moraes Augusto ter-me alertado para esse aspecto.) 


\section{TABELA 2}

Ocorrências de diegoûmai e seus derivados nos diálogos de Platão ${ }^{33}$

\begin{tabular}{|c|c|c|c|c|c|c|c|c|c|c|}
\hline Diálogos & $\frac{\dot{2}}{2}$ & $\underset{\Xi}{\check{\Xi}}$ & ن் & نัّ & 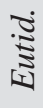 & 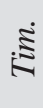 & $\begin{array}{l}\dot{8} \\
\text { ப் } \\
\text { I. }\end{array}$ & 灾 & '0 & مُ \\
\hline di h go u ma i & 7 & 14 & 3 & 4 & 3 & 1 & 0 & 2 & 0 & 1 \\
\hline ejpekdi h go uma i & 0 & 0 & 3 & 0 & 0 & 0 & 0 & 0 & 0 & 0 \\
\hline dihghsis & 14 & 0 & 0 & 1 & 1 & 2 & 2 & 0 & 1 & 0 \\
\hline Total & 21 & 14 & 6 & 5 & 4 & 3 & 2 & 2 & 1 & 1 \\
\hline
\end{tabular}

A mera exposição dos registros já será suficiente para indicar que a diegese constitui um recurso relevante, permitindo-nos, em benefício da brevidade, apenas considerar os usos do substantivo, que, além de em Platão, só se registra numa única passagem do corpus hipocraticum: ${ }^{34}$ a) em Eutidemo 275 d, a observação de Sócrates a Críton garante que toda a seqüência do diálogo é constituída pela diegese socrática da apresentação dos dois sofistas ["O que aconteceu depois disso, Críton, como lhe poderia contar (diegesaímen) bem? (...). Assim, eu, como os poetas, devo começar a diegese invocando as Musas e a Memória."]; b) as duas referências no Timeu indicam que o amplo discurso cosmológico de Sócrates se entende como diegese (assim, em 38e, ele diz que, a respeito dos "outros planetas", "talvez mais tarde, havendo tempo livre, eu poderia fazer uma diegese adequada", do mesmo modo que, em 48d, suplica ao "deus salvador" que os guarde de fazer uma "diegese absurda e insólita", conduzindo-os a uma "opinião verossímil”"); c) em Fedro 246a, Sócrates, após tratar dos três tipos de "loucura divina" e da imortalidade da alma, observa que, "a respeito da sua imortalidade, é suficiente [o que foi dito]; [dizer] o que ela é seria uma diegese em tudo e por tudo divina e longa, mas [dizer] com o que se parece, [uma diegese] humana e menor", dando início então à exposição sobre a parelha alada; d) em Górgias 465e, no fim da longa argumentação que acabara de fazer para demonstrar que a retórica é, para a alma, o correspondente da culinária para o corpo, Sócrates justifica-se, declarando que, "quando eu falava brevemente, você não entendia, nem era capaz de aproveitar nada da

33 Parmênides, Lísis, Protágoras, Górgias, Sofista, Menéxeno, Crítias, Leis; diálogo de atribuição duvidosa: Alcibíades 2; espúrio: Clitofonte.

34 Da dieta nas enfermidades agudas, 14: depois de ter discorrido sobre os benefícios do uso de vários tipos de vinho no tratamento das enfermidades agudas, o autor observa que "o vinho branco e encorpado foi louvado e criticado, freqüentemente e muitíssimo, já na descrição (d i g g h s i s) do vinho suave". 
resposta que eu lhe dava, mas tinha necessidade de diegese". Como se vê, diégesis pode aplicar-se tanto à narrativa propriamente dita de um diálogo (Eutidemo) e à exposição cosmológica em forma narrativa (Timeu), quanto à argumentação sobre a imortalidade da alma (Fedro) e a natureza da retórica (Górgias).

A famosa abertura do Teeteto dá-nos mais detalhes a esse propósito, da perspectiva da composição não mais de um discurso, mas do próprio texto escrito: a) Sócrates narrou (diegésato) a Euclides o diálogo (lógous hoùs dielékhthe) com Teeteto; b) Euclides escreveu um memorial (hypómnema), que trabalhou, consultando Sócrates cada vez que pôde; c) Euclides declara a Terpsíon que

escrevi então o lógos não com Sócrates narrando-me (diegoúmenon), como narrou (hos diegeîto), mas dialogando (dialegómenon) com os que disse ter dialogado [...]. Assim, a fim de, no escrito, por conveniência, não introduzir as diegeses entre os lógoi, tanto as relativas a ele próprio - quando dizia Sócrates: "e eu disse", ou "e eu falei" - quanto as relativas ao que respondia - como "ele concordou" ou "não se pôs de acordo" - por isso escrevi como se ele estivesse dialogando com seus interlocutores (autòn autoîs dialegómenon), tendo eliminado aquele tipo de coisas. $(143 b-c)$

Além de garantir-nos que Sócrates não só dialogava, como relatava em seguida seus próprios diálogos, o trecho mostra como se pode passar, na transmissão dos lógoi socráticos, por vários tipos de léxis: Sócrates valeu-se da diegese mista (como faz na República), mas Euclides escreveu uma diegese mimética (que, contudo, dá a entender que se trata de diegese do próprio Sócrates, à qual foi fiel). ${ }^{35} \mathrm{~A}$ oposição feita no Górgias entre o lógos que se faz por meio de perguntas e respostas e o diegético é esclarecedora, levando

35 Não é apenas de um diálogo para outro que a técnica diegética pode sofrer mudanças. Em Parmênides 137c, observa-se uma transformação da diegese mista para a mimética, quando, depois de referir a resposta de Aristóteles à indagação de Parmênides sobre quem responderia a suas questões, os verbos dicendi são totalmente abandonados, e o diálogo em estilo direto prossegue até o final. Convém reproduzir a passagem de um tipo de léxis ao outro, salientando como os "ele disse ele ter dito" preservam, até este ponto, os três níveis diegéticos, a saber: a) o de Aristóteles, que contou a Antifonte; b) o de Antifonte, que relata a Céfalo; c) e o de Céfalo, que é o narrador de primeiro nível e se dirige ao leitor: " - Quem então responderá a mim? [ele disse ele ter dito (eipeîn)]. O mais jovem? Pois é quem menos ergueria dificuldades, e o que mais responderia aquilo que pensa. $\mathrm{E}$, ao mesmo tempo, sua resposta seria para mim uma pausa. - Estou às tuas ordens para isso, Parmênides [disse ele Aristóteles ter dito (phánai tòn Aristotéle)]. Pois te referes a mim, dizendo o mais jovem. Pois bem! Pergunta, que eu responderei. - Seja pois, [disse ele que ele disse (eîen dé, phánai)]. Se um é, não é verdade que o um não seria múltiplas coisas? - Como poderia ser? - Logo, é preciso nem haver parte dele, nem ser ele um todo. - Por quê? - A parte, penso, é parte de um todo. - Sim. - Mas e o todo?..." (Tradução de Maura Iglésias e Fernando Rodrigues: PLATÃO. Parmênides. Rio de J aneiro: PUC-Rio; São Paulo: Loyola, 2003. p. 53. Os trechos postos entre colchetes recuperam as expressões dicendi abandonadas pelos tradutores.) 
a supor que há diegese quando um expositor assume inteira responsabilidade pelo desenvolvimento de um discurso narrativo ou argumentativo.

Ora, ao declarar que "tudo quanto dizem mitólogos e poetas é diegese", Platão, portanto, provê uma primeira delimitação do lógos daqueles que parece bastante abrangente. Esse lógos já havia sido definido antes como o "mito", o qual é, "como se diz, falso no todo, mas em que há também algo de verdadeiro" (pseûdos éni dè kaì alethê, 377a), ou seja, uma terceira espécie do lógos, intermediária entre as duas antes estabelecidas, a verdadeira e a falsa (376e). Assim, ao lógos dessa terceira espécie é que agora se ajunta mais um traço, no nível da léxis: o ser diegético. Podemos concluir que, enquanto diegético, o foco da análise se desloca do discurso para o diegetés, o mitólogo ou poeta que o conduz - e, de fato, o que está em julgamento não é propriamente a poesia (e a mitologia), mas o poeta (e mitólogo). Daí se entende como a distinção entre dois tipos de diegese, a simples e a mimética, possa aplicar-se também ao retor, como se faz em Rep. 396e. Todavia, nem tudo o que diz um retor é diégesis, pois esta constitui não mais que uma das partes de seu discurso, conforme o esquema apresentado no Fedro, ${ }^{36}$ o que se poderia estender também ao filósofo, como mostra o exemplo de Górgias 465 e, citado anteriormente, já que o próprio Sócrates usa do "falar brevemente" tanto quanto de diegese. Assim se entende a delimitação pretendida por Platão (e tão própria de seu método): diferentemente de em outros casos, não é em parte, mas no todo, que o lógos de poetas e mitólogos é diegético, o que não quer dizer que seja simplesmente "narrativo".

Para avaliar bem as conseqüências disso é inevitável trazer à consideração as funções da mímesis, que provê a diferenciação feita em 392d entre as três espécies de diegese. Procedamos por partes para compreender o raciocínio de Platão: a) não basta saber o que é o lógos de mitólogos e poetas, mas é preciso investigar também sua léxis; b) essa léxis define-se única e simplesmente como diégesis, embora esta não seja exclusiva de mitólogos e poetas (há também a diegese própria do orador, do historiador, do médico e do filósofo, que, todavia, utilizam também outros gêneros de discurso); c) assim, num primeiro nível, léxis e diégesis, no caso de mitólogos e poetas, são a mesma coisa, conforme se declara em 396d: "há pois uma certa espécie (eîdos) de léxis e diégesis em que exporia (diegoîto) quem é verdadeiramente nobre (kalòs kagathós), quando

36 Cf. Fedro 266d-267 a, em que se relacionam as seguintes partes: a) exórdio; b) exposição (diégesis) e testemunhos que Ihe dizem respeito; c) indícios; d) probabilidades; e) prova e contraprova; f) refutação e refutação complementar; g) insinuação e elogio indireto. Adoto a terminologia em português de J osé Ribeiro Ferreira (PLATÃO. Fedro. Lisboa: Edições 70, 1997. p. 102). 
tiver necessidade de falar algo, e outra espécie diferente (anómoion eîdos), da qual sempre se valeria e na qual exporia (diegoîto) quem for, por natureza e educação, contrário àquele"; d) em 397c, consideram-se três tipos de léxis (týpoi tês lexeos), que empregam "todos os poetas e os que dizem algo" (pántes hoi poietaì kaì hoí ti légontes), isto é, os dois tipos puros (sem mimese/através de mimese) e o tipo que mistura ambos (ex amphotéron tinì xynkerannýntes); d) em 397d, pergunta-se qual tipo será admitido na cidade: "dos puros, um dos dois (tôn akráton tòn héteron), ou o misturado" (tòn kekraménon); ${ }^{37} \mathrm{e}$ ) na mesma passagem, quando Adimanto responde que deve ser "o puro que imita alguém moderado" (tòn toû epieikoûs mimetèn ákraton), ${ }^{38}$ Sócrates acrescenta que, contudo, "o misturado é muito mais agradável para crianças e pedagogos"; f) anteriormente, em 396e, já se manifestara a preferência pela espécie mista: quando se trata de mimetizar "alguém indigno" de ser imitado, será escolhida "a diegese [...] tal qual nós, há pouco, descrevemos a respeito dos versos de Homero, e sua léxis [do poeta] participará de ambas, de mimese tanto quanto da diegese simples, mas havendo, num extenso lógos, pequena parte de mimese".

Portanto, são dois os tipos básicos (ou "puros") de léxis dos poetas: a diegese simples e a diegese mimética. O terceiro tipo nada mais é que mescla desses dois. ${ }^{39}$ Conclusão: do mesmo modo que nem toda diegese comporta

37 Os termos e a noção de "puro" (akr atos) e "misturado" (kekr a menos), Platão os toma do vinho que se bebe puro ou temperado com água, cf. República 562c-e (akrato $s$ el euqeri i ). Tratei da retomada da imagem platônica por Luciano em: A "pura liberdade" do poeta e o historiador. Ágora: Estudos Clássicos em debate, n. 9, p. 9-40, 2007.

38 A formulação de que se deve preferir "o [tipo] puro [de léxis] que imita o homem moderado" é curiosa, pelas seguintes razões: a) em princípio, considerando-se o que foi dito em $397 b-c$, tudo levaria a crer que se trata da "diegese simples", já que relacionada com alguém moderado (ep i ei kh ६ 5 ), que não se valeria, portanto, de todo tipo de harmonia e ritmo, nem adotaria toda sorte de variações (como pareceria próprio da "diegese mimética"); b) contudo, afirma-se que esse tipo de léxis é "imitador" (mi mh th sensato, admitindo-se, em conseqüência, que há nele algum grau de mimese. A contradição parece-me que só se resolve se tivermos em conta que o lógos de mitólogos e poetas, de que agora se discute a léxis, já fora definido como "ficção em que há algo de verdadeiro" (y eudo $\varsigma$ ehi ka i Va) h qh t, o que tornaria mitólogos e poetas sempre e em qualquer situação mi mh t a i v(como também o é o pintor em 595b-598d). Em resumo: o poeta, se poeta, mesmo quando utiliza a "diegese simples", mimetiza um diegeta que pode ser moderado ou não (e diegetas imoderados poderiam ser encontrados em outras esferas, por exemplo, nas assembléias e nos tribunais). Isso porque, mesmo quando fala como si mesmo, seu lógos constitui um pseûdos em que há sim algo de verdadeiro, mas permanece, no todo, pseûdos. Deveríamos então admitir que há uma léxis de poetas e mitólogos que mimetiza o caráter moderado (em princípio, a diegese simples), bem como outra que o faz com relação ao imoderado (a diegese mimética). Todavia, é preciso também admitir que essa opção pela diegese simples não se faz taxativamente (na verdade, a opção - de Adminanto, recorde-se, não de Sócrates - é pelo "tipo puro" de léxis que mimetiza o moderado), deixando aberta a possibilidade, no meu modo de entender, de que esse "tipo puro" pudesse ser também a diegese mimética que mimetizasse o caráter do homem moderado (como faz Platão ao apresentar a diegese socrática que é a própria República). Essa questão, todavia, merece um exame mais detalhado, impossível de ser levado a cabo neste artigo.

39 Sem dúvida, esse terceiro tipo é o preferido por Sócrates, conforme se declara em 396c-e: "o cidadão comedido (metrios anhr), quando chegar, na diegese, em algum discurso (lexin) ou ação (pra*in) 
mimese, nem toda mimese supõe diegese (conforme 397a, alguém pode mimetizar trovões, ventos, trombetas e flautas). Contudo, se há poesia (poíesis) há diegese ${ }^{40}$ (também, recorde-se, se há mitologia). Mas esta não se reduz a "narrativa", no sentido restrito como a entendemos, podendo englobar todas as formas de exposição: um poema de Safo (por exemplo, o famoso phaínetaí moi) ou uma elegia de Sólon são tão diegéticos quanto os poemas de Homero ou as tragédias de Sófocles, com a diferença de que, neles, não há mimese, enquanto representação do discurso do outro, pois é só o poeta quem fala como si mesmo, sem se "fazer semelhante a um outro pela voz ou pelo gesto" e "jamais se ocultando" (conforme a definição de mimese em Rep. 393c). Do mesmo modo, para tomar mais um exemplo da lírica, constitui diegese o fragmento sáfico $1 \mathrm{~V}$ (conhecido como "Hino a Afrodite"), com a diferença de que comporta também mimese, pois a deusa se dirige, em discurso direto, à própria Safo (“Quem, ó Safo, te maltratou?”), ou seja, esta, a poeta, oculta-se nessas passagens, buscando assemelhar-se à deusa cujo discurso mimetiza. ${ }^{41}$ Assim, não me parece correto afirmar que Platão tratou apenas dos gêneros narrativos, deixando de lado boa parte da produção poética grega. Pelo contrário, a afirmação de que "tudo quanto é dito por poetas e mitólogos é diegese" deve ser tomada em sua radicalidade e amplitude, pois parece que pretende abarcar, de fato, toda a mitologia (os mythoi em prosa) e poesia (os mythoi em versos). ${ }^{42}$

Assim, nosso esforço para compreender de modo mais exato o pensamento e a terminologia de Platão deve levar em conta o modo como o movimento de diérese se processa em República $376 \mathrm{e}-417 \mathrm{~b},{ }^{43}$ o que se poderia resumir

de um bom cidadão (androł agaqout, haverá de querer, como se ele próprio fosse aquele, discorrer (a paggevl ein) e não se envergonhará desse tipo de mimese. [...] Portanto, usará da diegese como nós há pouco descrevemos a respeito dos poemas de Homero (taVp mh rou eph) - e seu discurso (lexis) participará de ambas, tanto da mimese, quanto da diegese simples".

$40 \mathrm{Em} \mathrm{393c}$ afirma-se que, "se o poeta jamais se ocultasse a si mesmo, toda sua poesia e diegese (p o i b s i 5 te kaiVdihghsis) seria feita sem mimese".

41 A afirmação de Sócrates, em 379a, sugere que a lírica não está excluída do interesse platônico, pelo menos no que concerne ao lógos: "Como é o deus, é assim que sempre se deve reproduzir, tanto caso alguém o poetize em versos épicos, quanto em cantos, quanto na tragédia" (oips tugca rei of qeo $\$$ wh,

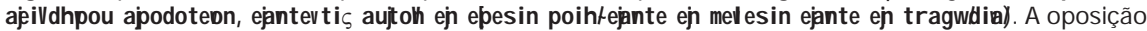
parece ser entre a poesia apenas metrificada, como na épica, e a cantada, como nas diversas espécies de lírica - a tragédia supondo os dois recursos. Devo essa observação criteriosa também a Maria das Graças de Moraes Augusto.

42 Restaria examinar as conseqüências da referência a "diegese de coisas que foram, são ou serão", o que não me parece indicar que se trate de narrativa de feitos passados, como é o entendimento comum. A expressão remete à fórmula de Hesíodo, Teogonia 38, ta vt ' ejpta ta vt ' és somena provt ' éprta. 0 exame dessa questão fica, contudo, para outro trabalho.

43 Ressalte-se que a própria exposição que se inicia é definida, em 376d, como se Sócrates e seus interlocutores estivessem en mugw/mugologouptes, ou seja, compondo um relato em prosa. Ora, se, do

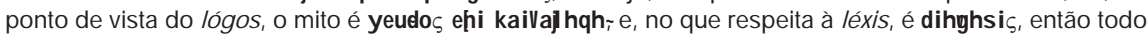


dessa forma: a) a educação (paidéia) tradicional, a qual se adota para os guardiões, divide-se em ginástica para o corpo e música para a alma (376e); b) a educação começa com a música, em que se encontram também os lógoi (376e), o que leva a supor que, nela, há dois aspectos: a música propriamente dita (compreendendo o canto e a melodia, retomados em 398c, bem como o ritmo, que volta à cena em 399e) e os lógoi; c) os lógoi se desdobram no lógos propriamente dito, ou seja, "o que se deve dizer" (hà lektéon), e na léxis, "como se deve dizer" (hos lektéon); d) a léxis supõe várias espécies (a de historiadores, médicos, oradores, filósofos), mas, no caso de poetas e mitólogos, reduz-se a diégesis; e) a diégesis, finalmente, distingue-se em diegese propriamente dita (haplè diégesis/ákratos diégesis) e em diegese mimética (dià miméseos/ákratos mímesis). Assim, numa leitura superficial, parece que música se opõe a lógos, do mesmo modo que lógos a léxis e diegese a mimese - e, de fato, isso tem uma função na argumentação, pois pode haver música como menos ou mais lógos (até sem lógos algum, ainda que não seja este o caso que interessa a Platão), do mesmo modo que diegese com menos ou mais mimese - até sem nenhuma mimese, embora pareça que, com relação a mitólogos e poetas, já que seu lógos é pseûdos, sempre haverá mimese em algum grau mínimo. Todavia, após percorrer os vários níveis da diérese, é preciso refazer o percurso, compreendendo a mimese como um traço que se pode ajuntar à diegese, do mesmo modo que a léxis diegética é o elemento que necessariamente se ajunta ao lógos de poetas e mitólogos, definindo-o no que tem de específico.

esse trecho da República se caracteriza como uma diegese ficcional (não sobre coisas que são ou foram, mas como serão ou, melhor, poderão vir ser), não poética, por não ser em versos, mas em prosa (como a dos mitólogos). 